\section{Quality Assurance Program to Ensure a Continuous Supply of High-quality Seed}

\author{
Hossein Robani
}

Addtional index words. total quality control, seed quality, quality system

Summary. Highly educated and demanding customers, complex business structures, rapidly changing technology, greater liability, and strong competition bring unprecedented pressures on the vegetable seed industry. An effective quality system involving all of the business functions (breeding, parent seed maintenance, production, processing, testing, seed treatment, packaging, marketing, and customer service) seems to be inevitable.

The future of the seed business belongs to companies that can provide continuous supplies of high-quality seed with necessary support and technical services and can afford investment in a rapidly advancing technology.

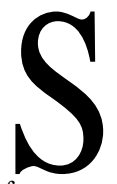

everal excellent quality control (QC)/ quality assurance $(\mathrm{QA})$ systems have been presented in variousconferences (Baskin, 1988; Delouche, 1986; Sayers, 1987). Sayers (1987) identified four general areas involving seed quality that must be considered in an effective QC program.

1. Physiological quality

ž germination

ž vigor

2. Physical quality

ž purity

ž physical condition (mechanical damage, size, etc.)

ž general appearance

ž moisture content

$\check{z}$ freedom from insects

ž plantability

3. Genetic quality

Ž varietal purity

Quality assurance manager, Ferry Morse Seed Co..

Modesto, CA 95352
4. Pathological quality

$\check{z}$ freedom from seed-borne disease

The rules for testing seed have been defined by the Federal Seed Act, and quality standards have been set by individual companies. However, the demand of customers for high-quality seed has been increasing rapidly to the highest achievable quality in any of the above-mentioned four areas.

Some of the factors affecting these four areas are:

1. Parent seed selection

2. Area and field selection

3. Seedling establishment

$\check{z}$ seedbed preparation

$\check{Z}$ moisture and temperature

ž soil crusting

ž soil-borne pathogen and toxic materials

Ž soil fertility

Ž planting

4. Cultural practices

žcultivation

$\check{Z}$ water and nutrient management

$\check{Z}$ pest and disease control

Ž roguing and field inspection

5. Harvesting

6. Processing

7. Treatment

8. Storage and shipping

A continuous, profitable supply of products at the level of seed quality that customers demand can only be achieved by a careful implementation of a QC/QA system in all the areas mentioned above.

Knittle (1989) defined seed quality as "the degree of genetic potential expressed and customer satisfaction achieved in seed products." Seed quality assurance was also defined as "an integrated system of seed business functions, each of which seeks to maximize the genetic potential and customer satisfaction in seed products."

Departments involved in a QA system are: plant breeding, parent seed, production research, engineering, seed production, quality testing, storageand distribution, and customeragronomic service.

Several other related QA or QC papers have been published by Mississippi State Univ. (Delouche, 1986; Hagar, 1982) and other publications of various organizations (Gill, 1989; Shultz, 1987).

Seeds are biological materials, and production of high-quality seed is highly dependent on Mother Nature. Therefore, obtaining seed with maximum genetic potential may not always be possible, considering the economy of the seed business and barriers involved in production. A more realistic definition for seed quality could be described as "a specific product for a specific market that can bring customer satisfaction, hold the market place for the company, and ensure reasonable return."
A QA program cannot be effectively implemented unless, in addition to complete management commitment to quality, every segment of the company understands the importance of the program and is committed to quality in its own department.

The rest of this paper introduces some of the factors influencing the effectiveness of a QA program, as described in BBP Handbook of Quality Management (Karlin et al., 1987). Since the book was written by people involved in largecompanies such as telephone, electronic, and other industries, I have made some modifications to adapt it to the seed industry.

\section{What Quality Means to Each Segment of the Company}

To develop a clear image of quality, we should look at what quality means to the customers and each segment of the company.

To the customer $\rightarrow$ Satisfaction and a firstrate image

To marketing $\rightarrow$ Confidence in the marketplace

To research \& development $\rightarrow$ Challenge for a superior variety

To quality management $\rightarrow$ Opportunity to contribute

To top management $\rightarrow$ Investment and a good return

To company $\rightarrow$ Reputation and profitability

\section{Who Is Responsible for Quality ?}

Marketing is responsible for the quality of the marketing specifications. Research and development is responsible for the development of superior varieties. Production and processing is responsible for delivery of high-quality seed. All support groups are responsible for the quality of their support products or services.

\section{Responsibilities of a Quality Assurance Program}

A) To protect against the shipping of products that will cause customer problems. This is accomplished by proper sampling of the endproduct for various tests to confirm to the required levels of physiological, physical, genetic and pathological qualities.

B) To aid the improvement of performance in all functional areas. This is accomplished by analyzing product evaluation results to identify opportunities for corrective action leading to the elimination of problems.

C) To influence the way the company thinks about quality and the manner in which various departments work together.

D) To analyze company performance by us- 
ing statistical procedures for measuring warranty costs, field problems, and customer complaints, product and processing costs, and improvements in the marketplace. Questions that must be asked in such an analysis include: 1) Are sales being gained or lost due to quality? 2) Do our customers have to be "sold" on our products or do the products speak for themselves? Accountability analysis is examined by asking: 1) Are problems routinely identified and corrected in all areas in a formal manner? 2) Are there organizational understandings? Who is held responsible for failure to supply and inferior quality'?

Because of the increasing complexity of the seed business, more intense regulation, and much greater liability, the necessity for an effective QA program is obvious. Unfortunately the role of QC/ QA programs, which are designed to ensure a continuous supply of high-quality product and to prevent delivery of inferior quality to customers, is frequently misunderstood and misperceived as policing. The role of the QC/QA can be viewed as: 1) a measurer of performance 2) an identifier of problems; and 3) a facilitator of quality improvements. Supportive participation by quality organizations in producing, processing, and identifying quality seed suitable for a specified market, and enhancement of product performance can improve the performance of the other departments, and will ensure a successful future for the company in a highly competitive market.

\section{Literature Cited}

Baskin, C.C. 1988 Quality enhancement through quality assurance. Proc. Short Course for Seedsmen, vol.30, Mississippi State Univ., Mississippi State.

Delouche, J.C. 1986. Quality control. Proc. Short Course for Seedsmen, Mississippi State Univ., Mississippi State.

Gill, N.S. 1989. Quality control in perspective. Nwsl. Assn. Offic. Seed Anal. 63:3.

Hagar, R.E. 1982. Quality assurance program for small grain seed. Proc. Short Course for Seedsmen, Mississippi State Univ., Mississippi State.

Karlin, E.W, J.T. Hagan, J. Procopio, R.S. Ullman. 1987. BBP handbook of quality management. Bureau Business Practice, Inc.

Knittle, K. 1989. Corn/sorghum/soybean quality control. SCST Annu. Mtng., Peoria, Ill.

Sayers, R.L. Quality control-A management tool. 1987 Short course for Seedsmen, Mississippi State Univ., Mississippi State, MS 39762.

Shultz, G. 1987. Successful quality assurance. Proc. Short Course for Seedsmen, Mississippi State Univ. Mississippi State. 